\title{
Pervasive NFC-based solution for the analysis of tourism data in an environment of smart cities
}

\author{
Eliana Andrea Concha Agredo / elianaca@unicauca.edu.co \\ Luis Carlos Martínez-Acosta / Icmartinez@unicauca.edu.co \\ Angela Chantre, Ph.D. (c) / achantre@unicauca.edu.co \\ Gustavo Ramirez-Gonzalez, Ph.D. / gramirez@unicauca.edu.co
}

Universidad del Cauca, Popayán - Colombia

\begin{abstract}
Detailed recording and analysis of visitor paths and individual mouse movements in real time of tens-of-thousands of visitors is one of the most important areas of tourism research, and to observe tourist movements a variety of techniques are available. New tracking techniques are explored and due to the advance of technology we can have information at any time and from anywhere (pervasive computing). This has been used to record movement information of tourists with high resolution. In these environments (tags environments) where the user interacts with the environment, an emerging technology called NFC (Near Field Communication) is providing a natural means of interaction between the users and their environment. This paper shows the implementation of an NFC-based pervasive solution that allows tourist tracking data to be obtained in real time; it is simplified and analyzed with the Markov chains method by experimental and statistical testing. It is also demonstrated that the movement of a tourist is influenced by the state or tourist site where he or she is to move to another, corroborating the hypothesis "that if you can capture the information left by tourists through technological tools, thanks to the processing of such information you can obtain a trace that is a sample of the activity which, through its display, allows decisions that promote tourism as part of the regional and national economy".
\end{abstract}

KEYWORDS Context; pervasive computing, smart cities; NFC; tourism; location; Markov chains analysis; movements and tourists.

\section{Solución ubicua basada en NFC para el análisis de da- tos turísticos en un ambiente de ciudades inteligentes}

PALABRAS CLAVE Contexto; computación ubicua; smart city; NFC;

turismo; análisis con cadenas de Markov; movimientos y turistas.

\begin{abstract}
RESUMEN El registro y el análisis detallado de las trayectorias del visitante y los movimientos individuales en tiempo real de las decenas de miles de visitantes es una de las áreas más importantes de la investigación en turismo. Para observar los movimientos turísticos, está disponible una variedad de técnicas. Nuevas técnicas de seguimiento se están explorando y gracias al avance de la tecnología es posible disponer en cualquier momento y desde cualquier lugar (computación ubicua) de la de información que se ha utilizado para registrar el movimiento de turistas, con alta resolución. En estos entornos (ambientes etiquetados) donde el usuario interactúa con su medio ambiente, una tecnología emergente conocida como Near Field Communication [NFC] ofrece una manera natural para la interacción entre los usuarios y su entorno. Este artículo elabora una propuesta ubicua, basada en NFC, que permite obtener datos turísticos en tiempo real que son analizados con el método de cadenas de Markov por medio de pruebas experimentales y estadísticas, gracias a que se demuestra que el movimiento de un turista está influenciado por el estado o sitio turístico donde se encuentre antes de pasar a otro, corroborando la hipótesis que indica que es posible capturar información dejada por los turistas por medio de herramientas tecnológicas, y que gracias al procesamiento de esa información se puede obtener una traza que muestre la actividad realizada, la misma que, por medio de su visualización permitirá la toma de decisiones que favorezcan la actividad turística como parte de la economía regional y nacional.
\end{abstract}

\section{Solução ubíqua baseada em NFC para a análise de da- dos turísticos em cidades inteligentes.}

RESUMO O registro e a análise pormenorizados dos percursos do visitante bem como os movimentos individuais em tempo real das dezenas de milhares de visitantes pertencem a uma das mais importantes áreas de pesquisa em turismo. Para observar os movimentos turísticos, encontra-se disponível uma variedade de técnicas. Novas técnicas de monitorização estão sendo exploradas e graças aos avanços da tecnologia é possível ter em qualquer momento e desde qualquer lugar (computação ubíqua) a informação que foi usada para registrar o movimento de turistas, com alta resolução. Nesses ambientes (ambientes etiquetados) onde o usuário interage com o seu ambiente, uma tecnologia emergente conhecida como Near Field Communication [NFC] fornece uma maneira natural para a interação entre os usuários e seu ambiente. Este artigo desenvolve uma proposta ubíqua, baseada em NFG, que permite obter dados turísticos em tempo real que são analisados com o método de cadeias de Markov através de testes experimentais e estatísticas, graças a que se demonstra que o movimento de um turista é influenciado pelo estado ou local turístico onde se encontra antes de passar para outro, confirmando a hipótese que é possível capturar informação deixada pelos turistas através de ferramentas tecnológicas, e que graças ao processamento dessa informação pode obter-se um traço que mostre a atividade realizada, o mesmo que, através da sua visualização permitirá tomar decisões que promovam o turismo como parte da economia regional e nacional.

PALAVRAS-CHAVE Contexto; computação ubíqua; cidade inteligente; NFC. 


\section{Introduction}

Tourism is one of the fastest growing industries in the world (Leiper, 2003). International tourist arrivals grew by $5 \%$ in 2013, reaching a record 1.087 million, according to the OMT Barometer of World Tourism (UNWTO, 2014). Despite global economic challenges, international tourism results were well above expectations, with an additional 52 million international tourists traveling around the world in 2013. For 2014, UNWTO forecast a $4 \%$ to $4.5 \%$ growth, once again above the long-term projections (UNWTO, 2014).

Tourism is a challenging field for the development of location-based services that provide mobile and personalized assistance and information services for tourists. Mobile tourist guides often include a wide range of navigation, route planning and re-planning, content delivery based on location, alerts on relevant events, payment and booking services (e.g. parking reservations).

For example, among the most important areas of tourism research is the recording and analysis of the trajectories of the tens of thousands of visitors and their individual movements in real time (DTTT, 2014; Pearce, 1995). According to Xia (2007), tourist movements can be studied from different disciplinary perspectives: geographers are interested in spatiotemporal tourist distribution (Pearce, 1995), psychologists are more likely to find the reasons behind tourism movements, for economists tourist movements are considered a starting point for the provision of services (Leiper, 2003; Ogilvie, 1933), while environmentalists are concerned about minimizing environmental damage as a result of these movements (Arrowsmith \& Inbakaran, 2002; McLaren, 2003).

There are plenty of techniques available to observe tourist movements. The traditional ones include those based on observations and interviews, which require the investigator to follow a tourist and register his movements (Dumont, Roovers, \& Gulinck, 2005), or the use of self-administered questionnaires which require that the participants trace their spatial movements in a cartographic map (Fennell, 1996; Wang \& Manning, 1999). Recently, new tracking techniques that use the global positioning system [GPS] (Arrowsmith, Chhetri, \& Zanon, 2005), a personal digital assistant [PDA], tracking devices (Hadley, Grenfell, \& Arrowsmith, 2003; Loiterton \& Bishop, 2005), cameras (Haritaoglu, Harwood, \& Davis,

\section{Introducción}

El turismo es una de las industrias de más rápido desarrollo en el mundo (Leiper, 2003). La llegada de turistas internacionales creció un 5\% en 2013, alcanzando un récord de 1.087 millones, según el Barómetro OMT del Turismo Mundial (UNWTO, 2014). A pesar de los desafíos económicos globales, los resultados del turismo internacional estuvieron muy por encima de las expectativas, con un adicional de 52 millones de turistas internacionales viajando por el mundo en 2013. Para 2014, la OMT previó un 4\% a un $4,5 \%$ de crecimiento, una vez más, por encima de las proyecciones a largo plazo (UNWTO, 2014).

El turismo es un dominio desafiante para el desarrollo de servicios basados en la localización que proporcionan servicios de asistencia e información personalizados y móviles a los turistas. Las guías de turismo móviles suelen incluir una amplia gama de servicios de navegación, planificación de rutas y re-planificación, entrega de contenido basado en la localización, alertas sobre eventos relevantes, servicios de pago y reserva de instalaciones (e.g., aparcamiento y reserva de asiento).

Así por ejemplo, dentro de las áreas más importantes de investigación turística se encuentra el registro y análisis de las trayectorias de las decenas de miles de visitantes y de sus movimientos individuales en tiempo real (DTTT, 2014; Pearce, 1995). Según Xia ( 2007), los movimientos turísticos puede estudiarse desde diferentes perspectivas disciplinarias: los geógrafos están interesados en la distribución espacio-temporal de los turistas (Pearce, 1995), los psicólogos son más propensos a buscar las razones detrás de los movimientos turísticos, para los economistas los movimientos turísticos son considerados un punto de partida para la prestación de servicios (Leiper, 2003; Ogilvie, 1933), mientras que los ambientalistas están preocupados por minimizar los daños ambientales como consecuencia de estos movimientos (Arrowsmith \& Inbakaran, 2002; McLaren, 2003).

Para observar los movimientos turísticos está disponible una variedad de técnicas. Las tradicionales incluyen aquellas basadas en observaciones y entrevistas, las cuales requieren que el investigador siga un turista individual y registre sus movimientos (Dumont, Roovers, \& Gulinck, 2005), o el uso de cuestionarios autoadministrados, el cual requiere que los participantes tracen sus movimientos espaciales en un mapa cartográfico (Fennell, 1996; Wang \& Manning, 1999). Recientemente, nuevas técnicas de seguimiento que usan sistemas de posicionamiento global [GPS] (Arrowsmith, Chhetri, \& Zanon 2005), asistentes digitales personales [PDA], dispositivos de seguimiento (Hadley, Grenfell, \& Arrowsmith 2003; Loiterton \& Bishop 2005), cámaras (Haritaoglu, Harwood, \& Davis, 2000), sistemas de cronometraje (O’Connor, Zerger, \& Itami, 2005) y teléfonos móviles (Bajaj, Ranaweera, \& Agrawal 2002) se han utilizado para registrar la información de movimiento de turistas con resultados de alta resolución. 
En este sentido, en los últimos tiempos, los avances en las Tecnologías de la Información y las Comunicaciones [TIC] han revolucionado todos los aspectos de la vida. La convergencia de detección generalizada y la creación de redes, conectividad inalámbrica y ordenadores más baratos, más rápidos y más pequeños, han hecho que sea más fácil de controlar de forma inteligente los sistemas y la autonomía de las personas, lo que se traduce en el concepto de Smart City (Naphade et al., 2011). Una Smart City es una ciudad que utiliza las TIC para hacer que tanto su infraestructura crítica, como sus componentes y los servicios públicos que ofrece sean más interactivos y eficientes, y que los ciudadanos puedan ser más conscientes de ellos (Fundación Telefónica, 2011; Buhalis \& Amaranggana, 2013). En una Smart City hay diferentes objetos con los que interactúa el ciudadano; gracias al aumento de la movilidad se pueden crear situaciones en el contexto del usuario, que hacen más dinámico al proceso. Luego, el apoyo de tecnologías ubicuas es esencial para mejorar la captura de la información relacionada con el contexto de usuario, pues permite la interacción con el entorno -la Inteligencia Ambiental AmI(Ducatel et al., 2001).

En estos ambientes, el usuario está rodeado de recursos ubicuos incrustados en objetos aumentados (etiquetas) en los cuales la interacción con el usuario, la visualización de información, el acceso a la personalización y la sensibilidad al contexto, juegan un papel muy importante (Loke, 2005; Ailisto et al. 2006). Una tecnología que está emergiendo -y es incipiente en el ámbito turístico- es Near Field Communications [NFG] (Coskun, Ozdenizci, \& Ok, 2013), la cual proporciona una forma natural de interacción entre el usuario y su entorno, una característica que hace que sea el candidato preferido para el desarrollo de ambientes inteligentes.

En los escenarios de aplicación de patrones de movimiento turístico en el entorno de una Smart City, la ubicación se detecta normalmente con aproximaciones de tecnología GPS, red de telefonía móvil celular, Wi-Fi, GPRS, etc., pero gracias a las ventajas que ofrece NFC - una tecnología de conectividad inalámbrica de corto alcance basada en estándares que hace la vida más fácil y conveniente para los consumidores de todo el mundo, por lo que es más fácil la realización de transacciones, el intercambio de contenido digital y la conexión de dispositivos electrónicos con un solo toque (NFG Forum, 2015)-, esta tecnología se ha utilizado en esta investigación para implementar una solución ubicua, que permite obtener los datos de la trayectoria de un turista en tiempo real, para ser simplificados y analizados. Este análisis puede llevarse a cabo utilizando métodos como: minería de datos, específicamente expectativa de maximización [EM] de agrupación para identificar los patrones de movimiento espacio-temporal de los turistas para diferentes topologías turísticas (Kuo et al. 2005; Wang, Lim, \& Hwang, 2006; Xia \& Arrowsmith, 2005); y métodos estadísticos, como los modelos log-lineales, la regresión logística y las cadenas de Markov. Por ejemplo, las técnicas
2000), timing systems (O’Connor, Zerger, \& Itami, 2005) and mobile telephones (Bajaj, Ranaweera, \& Agrawal, 2002) have been used to record information on tourist movements with high resolution results.

In this regard, in recent years, advances in Information and Communications Technology [ICT] have revolutionized all aspects of life. The convergence of generalized detection and the creation of networks, wireless connectivity and cheaper, faster and smaller computers has made it easier to intelligently control systems and people's autonomy, resulting in the concept of the Smart City (Naphade et al., 2011). A Smart City is a city that uses ICT to make both its critical infrastructure, its components, and public services that it offers more interactive and efficient, and its citizens more aware of them (Fundación Telefónica, 2011; Buhalis \& Amaranggana, 2013). In a Smart City there are different objects which a citizen can interact with; thanks to the increase of mobility, situations in the context of the user can be created, making the process more dynamic. Then the support of ubiquitous technologies is essential to enhance the capture of information related to the user context, because it allows interaction with the environment -the environmental intelligence--(Ducatel et al., 2001).

In these environments, the user is surrounded by ubiquitous resources embedded in objects (tags) in which user interaction, information visualization, access to personalization and context awareness play a very important role (Loke, 2005; Ailisto et al., 2006). A technology that is emerging -and is incipient in the touristic field- is Near Field Communications [NFG] (Coskun, Ozdenizci, \& Ok, 2013), which provides a natural means of interaction between the user and his environment, a feature that makes it the choice for the development of intelligent environments.

In the application scenarios of touristic movement patterns in the environment of a Smart City, the location is normally detected with approximations based on GPS, the mobile cellular network, Wi-Fi, GPRS, etc., but thanks to the advantages that NFG provides -a short-range wireless connectivity technology based on standards that makes life easier and convenient for worldwide consumers, so it is easier to conduct transactions, exchange digital content and connect electronic devices with a single touch (NFG Forum, 2015)-, this technology has been used in this research to implement a ubiquitous solution that allows the path of a tourist to 
be obtained in real time, to be simplified and analyzed. This analysis can be performed using methods such as: data mining, specifically expectation maximization [EM] clustering to identify spatiotemporal patterns of tourists for various touristic topologies (Kuo et al., 2005; Wang, Lim, \& Hwang, 2006; Xia \& Arrowsmith, 2005); and statistical methods, such as log-linear models, logistic regression and Markov chains. For example, Markov chains techniques have been used to explain human migration patterns (Zimmermann \& Constant, 2003; Tobler, 1997), for modeling human random walks (Spitzer et al., 1964) and for predicting the distribution of the population within a given area during a certain time interval.

This paper describes a ubiquitous solution based on NFG for the tourism industry in the context of smart cities, which allows the tracking of touristic movements in real time, to be analyzed later through experimental tests and statistics by the Markov chain method proposed by Xia, Zeephongsekul, and Arrowsmith (2009), thanks to the proof of the hypothesis of dependence between the relative movement of a tourist at a predecessor tourist attraction and at a successor attraction, demonstrating that the tourist is influenced by the state or touristic place where he is, to move to another. It is noteworthy that the movement patterns of tourists are essential for tourism planners, in the decision-making on the development of touristic products and the planning of destinations and marketing; they also contain elements of information that can be used to design better tour packages that offer more attractive combinations of places of interest, as well as for developing travel guidance policies and marketing services.

According to the context presented, the following sections have been defined: in Section 2 the state of the art is presented, considering some related work; Section 3 shows the system architecture; experiments and results are presented in Sections 4 and 5 shows the conclusions and future work.

\section{State of the art}

In the application domain of tourism, previous efforts to develop location-based applications are numerous. The GUIDE system (Cheverst et al., 2000) is one of the first works that offers tourists location-based information via a Personal Digital Assistant [PDA]. Another application that provides tourists with recommendations and de cadenas de Markov se han utilizado para explicar los patrones humanos de migración (Zimmermann \& Constant, 2003; Tobler, 1997), para el modelado de caminatas aleatorias humanas (Spitzer et al. 1964) y para la predicción de la distribución de la población dentro de un área dada, durante un cierto intervalo de tiempo.

En este trabajo se describe una solución ubicua basada en NFG para el sector turístico en el contexto de las ciudades inteligentes, que permite el seguimiento de los movimientos turísticos en tiempo real, para posteriormente ser analizados a través de pruebas experimentales y estadísticas mediante el método de la cadena de Markov propuesto por Xia, Zeephongsekul y Arrowsmith (2009), gracias a que se comprueba la hipótesis de dependencia entre la relación del movimiento del turista de un lugar turístico predecesor a un lugar turístico sucesor, demostrando que el movimiento de un turista está influenciado por el estado o sitio turístico donde se encuentra, para pasar a otro. Es importante mencionar que los patrones de movimiento de turistas son esenciales para los planificadores de turismo, en la toma de decisiones sobre el desarrollo de productos turísticos y en la planificación de destino y comercialización; también contienen elementos de información que podrían utilizarse para el diseño de mejores paquetes turísticos, que ofrezcan combinaciones más atractivas de lugares de interés, así como para el desarrollo de políticas de orientación de viajes y servicios de marketing.

De acuerdo con el contexto presentado, se han definido las siguientes secciones: en la sección II se presenta el estado del arte, considerando algunos trabajos relacionados; la sección III muestra la arquitectura del sistema; los experimentos y resultados se presentan en la sección IV; y la sección $\mathrm{V}$ se ocupa de las conclusiones y los trabajos futuros.

\section{Estado del arte}

En el dominio de aplicación del turismo son numerosos los esfuerzos previos para desarrollar aplicaciones basadas en ubicación. El sistema GUIDE (Cheverst et al. 2000) es una de los primeros trabajos que ofrece a los turistas información basada en la localización por medio de una Personal Digital Assistant [PDA]. Otra aplicación que proporciona a los turistas recomendaciones y servicios sensibles al contexto es COMPASS (Van Setten, Pokraev, \& Koolwaaij 2004). Así mismo, Chon y Cha (2011) presentan un proveedor de contexto basado en teléfonos inteligentes que funciona en tiempo real, utilizando el acelerómetro, la brújula digital, el WiFi y el GPS, para rastrear e identificar puntos de interés con precisión a nivel de espacio, automáticamente. Otra guía turística contextual para la ciudad de Lancaster fue desarrollada y desplegada en por Davies et al., (2001), la cual ofrece viajes a la medida para los visitantes, adaptando su comportamiento a los cambios en la ubicación de un usuario, en función de los intereses del visitante, su ubicación, el tiempo disponible, las limitaciones financieras y de 
movilidad, y las condiciones climáticas locales, adoptando un enfoque centrado en la red.

Del lado de seguimiento de turistas, así como el desarrollo de los computadores personales revolucionó el uso de los Sistemas de Información Geográfica [GIS] desde la perspectiva de los usuarios, las TIC ofrecen nuevas oportunidades para el análisis espacial. Entre las novedades está el uso de dispositivos GPS y teléfonos celulares, pues ambos permiten el seguimiento de los turistas en el espacio-tiempo. Por ejemplo, en su trabajo, ahas et al., (2007) analizan la estacionalidad del consumo de espacio de los turistas extranjeros en Estonia, utilizando un dataset de posicionamiento móvil con datos de roaming anónimos, por medio de coordenadas, el cual ha sido llamado «Método de Posicionamiento Social». Dicho método tiene una amplia gama de aplicaciones, incluyendo, tanto una mejora en la recolección de datos respecto del que se realiza a través de métodos tradicionales (e.g., los diarios), como mejoras en la gestión, la planificación y las aplicaciones de marketing. En otro ejemplo, Russo, Clave, y Shoval (2010) destacaron la posibilidad de utilizar datos agregados obtenidos a partir de los receptores GPS con el fin de comprender mejor el impacto de los visitantes en los destinos, basándose en la práctica y los resultados de un experimento de seguimiento en el parque temático de atracciones «Port Aventura», el parque temático «Mini Israel» (dos ambientes al aire libre cerrados), la ciudad vieja de Akko en Israel - una pequeña ciudad histórica- y Hong Kong. De forma similar Tchetchik, Fleischer, y Shoval (2009) mostraron cómo los datos espacio-temporales de alta resolución registrados por las unidades de GPS podrían utilizarse para los visitantes del segmento a la ciudad vieja de patrimonio de Acre en Israel, demostrando que ésta técnica de seguimiento con precisión del comportamiento temporal y espacial de los visitantes supera las limitaciones conocidas de los métodos de recolección de datos tradicionales.

Por otro lado, los teléfonos móviles también ofrecen oportunidades significativas para el análisis de comportamiento de los turistas a través de varias escalas (Asakura \& Iryo 2007). Por ejemplo, Girardin, Vaccari, Gerber, Biderman, y Ratti (2009) utilizaron la distribución y densidad de huellas digitales para examinar el atractivo del espacio urbano para los visitantes, en un estudio de caso de un proyecto de arte público en la zona de las Cataratas de la ciudad de Nueva York, haciendo uso de los datos dinámicos que generan los visitantes, tales como la densidad y la distribución de las llamadas telefónicas, las fotos tomadas en diferentes áreas de interés y tiempo.

Tiru, Kuusik, Lamp, \& Ahas (2010) analizan el funcionamiento de una herramienta de monitorización de turismo en línea basada en posicionamiento móvil que utiliza como fuente de datos los archivos de registro de los operadores en el cual las ubicaciones de partida de las actividades de llamadas de los clientes de roaming extranjeros han sido almacenadas - la base de datos es anónima y la identidad de context-sensitive services is COMPASS (Van Setten, Pokraev, \& Koolwaaij, 2004). Likewise, Chon and Cha (2011) present a context provider based smartphone that works in real time, using an accelerometer, digital compass, WiFi and GPS to track and identify places of interest with space level accuracy, automatically. Another contextual touristic guide for the city of Lancaster was developed and deployed by Davies et al. (2001), offering customized trips for visitors, and adapting its behavior to the changes in the user's location, depending on the visitor's interests, location, available time, financial and mobility limitations, and local climatic conditions, adopting a network-centric approach.

From the tourist-tracking field, as well as the development of personal computers revolutionizing the use of Geographic Information Systems [GIS] from the perspective of users, ICT offers new opportunities for spatial analysis. Among the new features is the use of GPS devices and cellphones, as both allow the tracking of tourists in space and time. For example, Ahas et al. (2007) analyze the seasonality of space consumption of foreign tourists in Estonia, using a dataset of anonymous mobile positioning with data roaming anonymous, by coordinates, which has been called the «Social Positioning Method». This method has a wide range of applications, offering both an improvement in data collection in respect of the data collected through traditional methods (e.g. diaries) and improvements in the management, planning and marketing applications. In another example, Russo, Clave, and Shoval (2010) highlighted the possibility of using aggregate data obtained from GPS receivers in order to better understand the impact of visitors on destinations, based on practice and the results of a monitoring experiment in the «Port Aventura» theme park, the «Mini Israel» theme park (two outdoor closed environments), the old city of Akko in Israel-a small historic city- and Hong Kong. Similarly, Tchetchik, Fleischer, and Shoval (2009) showed how the spatiotemporal high resolution data recorded by GPS units could be used to track visitors to a segment of the old city of Acre in Israel, demonstrating that this accurate tracking technique of the temporal and spatial behavior of visitors exceeds the known limitations of traditional methods of collecting data.

On the other hand, mobile phones also offer significant opportunities for the analysis of tourist behavior through multiple scales (Asakura \& Iryo, 2007). For 
example, Girardin, Vaccari, Gerber, Biderman, \& Ratti (2009) used the distribution and density of fingerprints to examine the attractiveness of urban space for visitors, in a case study of a public art project in the Falls area of New York city, using dynamic data generated by visitors, such as the density and distribution of phone calls, and photos taken in different areas of interest and time.

Tiru, Kuusik, Lamp, \& Ahas (2010) analyze the operation of an online monitoring tool of tourism based on mobile positioning using as the data source the log files of operators in which the starting locations of call activities of foreign roaming customers have been stored -the database is anonymous and the identity of the owners of mobile phones and the phone numbers are strictly protected in accordance with European directives. Also, Tiru et al. (2010) developed a methodology to determine the repeat visits by tourists to a destination using the number, duration, frequency and geography of visits, in order to identify repetition of visitors to a particular area.

Regarding methods for observing and understanding a digital city (Smart City) and the temporary space capture, O'Neill et al. (2006) show how to understand the city through a system that integrates physical forms and digital forms, as well as relationships established with people and users; they also describe how Bluetooth devices have been used in methods that permit observation, recording and modeling of the physical, digital and social city, as well as giving a different view of the representation of information through spatial syntax, which has the objective of understanding how the spatial structure of the city is related to aspects of their social role, being based mainly on spatial syntax, representing the city through nodes and links, and forming an axial map of the streets.

Regarding the applicability of NFG technology in monitoring touristic movements, a unique close solution was given by Borrego-Jaraba, Ruíz, \& Gómez-Nieto (2011); it is intended to help the user find the location of points of interest within the city and browse through them, using mobile phones with NFC built-in and smart posters scattered throughout the city. Similarly, there are several works that speak about the opportunities of NFC technology in smart cities, in the tourism industry. For example, Ronay and Egger (2013) focus on understanding symptoms that indicate the future involvement of the NFG technology in its role within the concepts of Smart City. Meanwhile, Pesonen and Horster (2012), in los propietarios de teléfonos móviles, y números de teléfono están estrictamente protegido de conformidad con las directivas europeas). Asimismo, Tiru et al. (2010) elaboraron una metodología para determinar las visitas repetidas de los turistas a un destino, utilizando el número, la duración, la frecuencia y la geografía de las visitas, con el fin de identificar la repetición de visitantes en un área en particular.

En cuanto a los métodos para observar y comprender una ciudad digital (Smart City) y la captura espacio temporal, O’Neill et al., (2006) muestran cómo entender la ciudad a través de un sistema que integra formas físicas y formas digitales, además de las relaciones que se establecen con la gente y con los usuarios; también describen la forma cómo se han utilizado los dispositivos bluetooth para obtener métodos que permitan observar, registrar y modelar la ciudad física, digital y social, así como una visión diferente de la representación de la información a través de la sintaxis espacial, que tiene como fin entender cómo la estructura espacial de la ciudad está relacionada con los aspectos de su función social, fundamentándose, principalmente, la sintaxis espacial, en la representación de la ciudad a través de nodos y enlaces, formando un mapa axial de las calles.

En cuanto a la aplicabilidad de la tecnología NFG en el seguimiento de los movimientos turísticos, una única solución cercana fue propuesta por Borrego-Jaraba, Ruíz, \& Gómez-Nieto (2011); ellas está orientada a ayudar al usuario a encontrar la ubicación de los puntos de interés dentro de la ciudad y a navegar a través de ellos, usando teléfonos móviles con la tecnología NFC incorporada y pósters inteligentes diseminados a lo largo de la ciudad. De manera similar, existen varios trabajos que hablan acerca de las oportunidades de la tecnología NFG en las ciudades inteligentes, en el área del turismo, así por ejemplo Ronay y Egger (2013) se enfocan en comprender los síntomas que indican la futura implicación de la tecnología NFG en su papel dentro de los conceptos de Smart City. Por su parte, Pesonen y Horster (2012) en su investigación sobre la tecnología NFC, la revisan y clasifican en cuatro temas: modelos de negocio y los ecosistemas; software y aplicaciones; seguridad y hardware; y amenazas y problemas. Mencionan también las aplicaciones actuales y potenciales de la tecnología NFG en el turismo y presentan las contribuciones de la gestión del estudio. Otro ejemplo lo presentan Buhalis y Amaranggana (2013), cuyo trabajo tiene como objetivo aprovechar, desde el desarrollo de Smart Cities, la conceptualización de un framework para los destinos turísticos inteligentes, a través de la exploración de las aplicaciones turísticas en un destino, haciendo frente a las oportunidades y los desafíos que se presentan.

Finalmente, aunque varios trabajos relacionados muestran prototipos que ofrecen enrutamiento basado en la ubicación geográfica de los usuarios móviles -típicamente obtenida a través de la red o en otros dispositivos móviles, tales como los receptores GPS, por lo que existe una dependencia de estas redes sobre la base de dispositivo de iden- 
tificación personal y de alto el consumo de energía-, no se han explorado alternativas basadas en NFG que aprovechen sus ventajas y oportunidades, la cuales son múltiples: con NFG los usuarios de teléfonos móviles pueden intercambiar de forma segura datos e información con otros puntos habilitados con NFC y etiquetas correspondientes; no hay necesidad de complicados emparejamientos, como en el caso de bluetooth; debido a la proximidad inmediata, no hay ningún malentendido en cuanto a los dispositivos entre los cuales la comunicación se establece; y NFG también puede ser idealmente conectado con otros protocolos como WLAN, UMTS o bluetooth (Egger, 2013), para permitir el seguimiento de los movimientos de un turista en una Smart City en el espacio-tiempo.

\section{Cadenas de Markov para modelar la actividad turística}

Los movimientos de turistas pueden ser modelados desde una perspectiva geográfica de nivel micro o a nivel macro. En este sentido, los movimientos en el plano macro, en términos de escala espacial, se refieren al movimiento de un lugar (área) a otro. La resolución temporal de los movimientos en el nivel macro se mide en horas, días, semanas o años. A nivel micro una secuencia de movimiento se representa como una colección de puntos espaciales (x, y) en un sistema de coordenadas y en la resolución temporal de minutos o incluso segundos. Los economistas, por lo tanto, pueden determinar la prestación de servicios basados en la investigación del movimiento turístico a nivel macro, realizada por geógrafos, mientras los ecologistas y los psicólogos pueden compartir el conocimiento de los movimientos turísticos a nivel micro, con geógrafos (Xia, 2007).

A nivel micro los movimientos son representados por un proceso estocástico continuo $\left\{X_{\mathrm{t}}\right\} t \in T$, donde $T=[0, \infty)$, que toma valores en un espacio de estados $S$. Los estados $S$ consisten en varios puntos espaciales georefenciados que representan las localizaciones de los movimientos de las personas, denominado así el espacio de estado continuo. Por otra parte, en un destino turístico como una ciudad, se da el caso en que se presente un modelado del movimiento espacio-temporal de los lugares de interés del turista, el espacio de estado $S$ puede ser considerado como el compendio de los diferentes sitios de interés, por lo tanto, $S$ es discreto.

A nivel macro los movimientos del turista son representados por un proceso estocástico continuo $\left\{X_{\mathrm{t}}\right\} t \in T$, donde $T=1,2,3, \ldots$ que toma valores en un espacio de estados $S$. En este proyecto el proceso del movimiento se centra en el modelamiento a nivel macro y en un espacio de estado $S$ discreto. De esta manera:

$$
S=A_{1} ; A_{2} ; A_{3}, \ldots, A_{k}
$$

De esta manera $A_{i}$ donde $i=1,2,3, \ldots k$ representa las atracciones turísticas y Al representa el estado OUT que es la región exterior al espacio $S$.

El proceso estocástico se modela representando el movi- their research on NFG technology, reviewed and classified it into four themes: business models and ecosystems; software and applications; security and hardware; and threats and problems. They also mention the uses, current and potential, of NFG technology in tourism applications, and present the contributions of management in the study. Another example is presented by $\mathrm{Bu}-$ halis and Amaranggana (2013), whose work aims to take advantage, from the development of Smart Cities, of the conceptualization of a framework for intelligent touristic destinations, through exploration of the applications of a touristic destination, facing the opportunities and challenges that arise.

Finally, although several related works show prototypes that offer routing based on the geographical location of mobile users -typically obtained through the network or other mobile devices such as GPS receivers, so there is a dependence of these networks on the base of personal identification devices, and high energy consumption-, alternatives based on NFC that take advantage of its benefits and opportunities, which are manifold, have not been explored: with NFC mobile phone users can securely exchange data and information with other NFG-enabled points and corresponding tags; there is no need for complicated pairings, as in the case of Bluetooth; due to the close proximity, there is no misunderstanding about the devices between which communication is established; and NFG can also be ideally connected with other protocols such as WLAN, UMTS or Bluetooth (Egger, 2013) to allow monitoring of the movements of a tourist in a Smart City in space and time.

\section{Markov chains for modeling the touristic activity}

The movements of tourists can be modeled from a geographic perspective at micro level or macro level. In this sense, the movements in the macro plane, in terms of spatial scales, refer to movement from one location (area) to another. The temporal resolution of the movements at the macro level is measured in hours, days, weeks or years. At the micro level a movement sequence is represented as a collection of spatial points $(x, y)$ in a coordinate system and the time resolution in minutes or even seconds. Economists can therefore determine the provision of research-based touristic movement services at macro level, performed by geographers, while environmentalists and psychologists can share knowledge of touristic movements at the micro level with geographers (Xia, 2007). 
At the micro level, movements are represented by a continuous stochastic process $\left\{X_{t}\right\} t \in T$ where $T=[0, \infty)$, that takes values in a space of $\mathrm{S}$ states. The states $\mathrm{S}$ consist of several geo-referenced spatial points that represent the locations of the movements of people, the so-called continuous state space. Moreover, in a touristic destination like a city, the modeling of spatiotemporal movements of a tourist's places of interest is possible, and the state space $\mathrm{S}$ can be considered as the compendium of the different sites of interest; therefore, $\mathrm{S}$ is discrete.

At the macro level, the tourist's movements are represented by a continuous stochastic process $\left\{X_{t}\right\} t \in T$ where $T=1,2,3, .$. , that takes values in a state space $S$. In this project, the process of movement focuses on macro-level modeling and in an $\mathrm{S}$ state discrete space. Thus:

$$
S=A_{1} ; A_{2} ; A_{3}, \ldots, A_{k}
$$

Thus $A_{i}$ where $i=1,2,3, \ldots k$, represents touristic attractions and Al represents the OUT state that is the region outside the space $\mathrm{S}$.

The stochastic process is modeled representing the movement of the tourist in $\mathrm{S}$ by a discrete stationary Markov chain, where each movement occurs after a jump step. In this manner, the tourist movement over a sequence of time $t=1$ to $t=m$ is represented as:

$$
M(m)=A_{i 1} ; A_{i 2} ; A_{i 3}, \ldots, A_{i m}
$$

where A1 represents the final state reached, OUT. This is because, by the nature of a tourist, he must always end his visit. Then the addition of this state is assumed as a state of absorption, since the process terminates once that state is reached (Xia, Zeephongsekul, \& Arrowsmith, 2009).

\section{Architecture of the ubiquitous system of touristic data analysis}

Ubiquitous computing is an area of rapid development, which has been enhanced by constant technological advances, which continue to rise thanks to the increasing computing capabilities of devices. This ubiquitous solution based on NFG allows touristic data to be obtained in real time, then analyzed with the Markov chains method, providing a natural means of interaction of tourists with their surrounding environment, specifically the ubiquitous resources embedded in objects (tagged sites) in a Smart City. miento del turista en $S$ por una cadena de Markov estacionaria discreta, donde cada movimiento ocurre después de un paso de salto. De esta forma, el movimiento del turista sobre una secuencia de tiempos $t=1_{\mathrm{a}} t=m_{\text {se representa }}$ como:

$$
M(m)=A_{i 1} ; A_{i 2} ; A_{i 3}, \ldots, A_{i m}
$$

Donde A 1 representa el estado final alcanzado OUT. Esto se debe a que, por connotación de turista, él debe finalizar siempre su visita. Así el adicionar este estado es asumido como un estado de absorción, ya que el proceso termina una vez se llega a ese estado (Xia, Zeephongsekul, \& Arrowsmith 2009).

\section{Arquitectura del sistema ubicuo de análisis de datos turísticos}

La computación ubicua es un área de rápido desarrollo, que se ha visto impulsada por los constantes avances tecnológicos, los cuales se mantienen en aumento gracias a las mayores capacidades computacionales de los dispositivos. Esta solución ubicua basada en NFC permite obtener datos turísticos en tiempo real, que son analizados con el método de cadenas de Markov, ofreciendo así una manera natural de interacción de los turistas con su entorno circundante, específicamente con los recursos ubicuos incorporados en objetos (sitios etiquetados) en una Smart City.

La Figura 1 muestra la arquitectura cliente-servidor general de la solución propuesta. En esta solución existen etiquetas NFG distribuidas a lo largo de los sitios de interés de la ciudad inteligente, las cuales contienen una URI que desencadena la información visual, gráfica y textual sobre el lugar accedido.

Como se observa en la Figura 1, los componentes funcionales en el modelo de interacción son cuatro: el escenario, las etiquetas inteligentes, la aplicación móvil y el servidor.

De esta forma, cuando el usuario toca con su dispositivo NFG cualquiera de las etiquetas inteligentes que se encuentran en los diferentes sitios turísticos de la ciudad, la aplicación móvil es capaz de leer la información almacenada en la etiqueta; en ese momento, si el dispositivo tiene conectividad, se despliega en su pantalla la página web oficial del sitio turístico; de lo contrario, una imagen y la descripción básica del mismo se carga por defecto. Además de desplegar el contenido informativo en pantalla, el teléfono móvil almacena la información del sitio visitado y establece una comunicación HTTP con el servidor por medio de un servicio web que es utilizado para registrar la visita y el tiempo obtenido, en este caso, la solicitud se envía a través de los módulos de comunicación del teléfono móvil.

Del lado del servidor, el servicio web se encarga de recibir la solicitud y procesarla con el fin de obtener la información enviada desde el dispositivo móvil, la cual está compuesta por la información de su identificación-a través de su IMEI- y la información de la visita - a través del identificador único del sitio turístico visitado-; en este caso, ésta es procesada por el Service Registry Manager, el cual almacena la información en su 


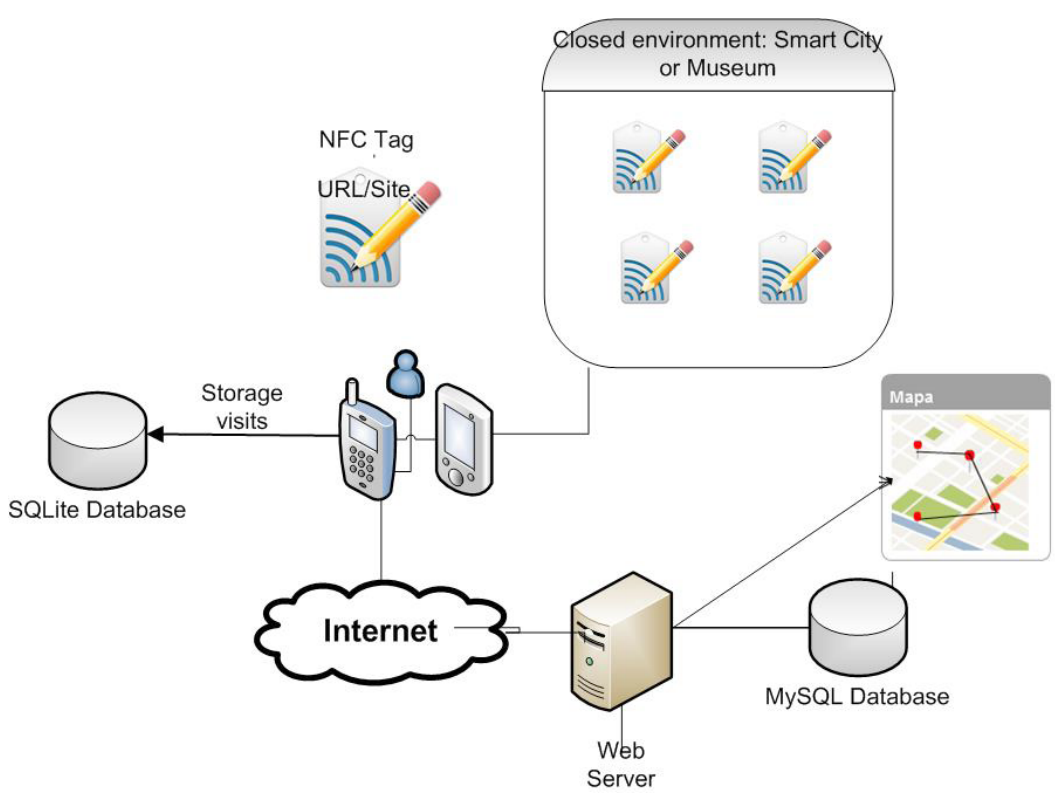

Figure 1. Architecture of the ubiquitous system of touristic data analysis / Figura 1. Arquitectura del sistema ubicuo de análisis de datos turístico
Figure 1 shows the overall client-server architecture of the proposed solution. In this solution NFC tags are distributed over the places of interest in the intelligent city, and contain a URI that triggers the visual, graphical and textual information about the place accessed.

As shown in Figure 1, there are four functional components in the interaction model: scenario, smart tag, the mobile application and the server.

In this way, when the user touches with his NFC any of the smart tags that are in the different touristic places of the city, the mobile application is able to read the information stored on the tag; at that time, if the device has connectivity, the official website of the tourist site is dis- base de datos y envía de vuelta una respuesta a la aplicación móvil, quien se encarga de mostrarla de una manera apropiada. El diagrama de la Figura 2 muestra este proceso.

Componentes del sistema de registro de la actividad turística

Esta propuesta es una arquitectura distribuida que consta de tres módulos principales, tal como se representa en la Figura 3:

- Smart tags (etiquetas inteligentes): objeto que representa una ubicación específica, como una empresa, en este caso, un punto de interés turístico o cualquier otro lugar en el escenario de aplicación, que está marcado.

- Cliente móvil: aplicación que se ejecuta en los dispositivos móviles de los usuarios, la cual gestiona la inte-

played on the screen; otherwise, a picture and a basic description thereof is loaded by default. In addition to displaying the information content on the screen, the mobile phone stores the information on the place visited and establishes an HTTP server communication via a web service that is used to record the visit and the time obtained, and in this case, the request is sent through the communication modules of the mobile phone.

On the server side, the web service is responsible for receiving and processing the request in order to obtain the information sent from the mobile device, which consists of the identification information - via its IMEI- and visit informa-

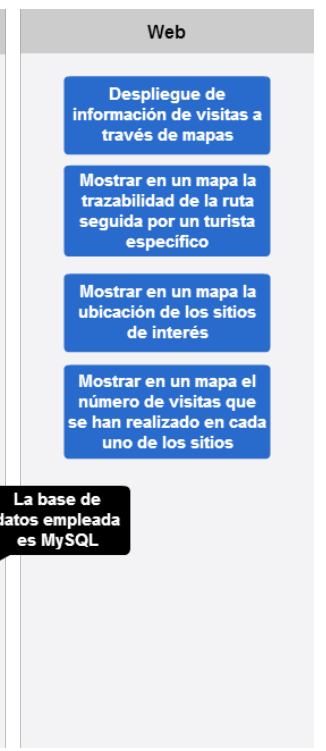

Figure 2. Flow chart of the process / Figura 2. Diagrama de flujo del proceso tion -through the unique identifier of the touristic place visited; in this case, it is processed by the Service Registry Manager, which stores the information in its database and sends back a response to the mobile application, which is responsible for displaying it in a proper way. The diagram in FIGURE 2 shows this process.

\section{Components of the touristic activity registry system}

This proposal is a distributed architecture which consists of three main modules, as depicted in Figure 3: 
- Smart tags: an object that represents a specific location, such as a company, in this case, a point of interest or any other place on the implementation scenario, which is tagged.

- Mobile client: an application that is executed on the user's mobile devices, which manages the interaction with the user through a graphical interface, showing information resources provided by the server. It is also the NFG tags reader. The communication is established in passive mode, because the mobile device is the one with the power source and the signal generated for the data exchange.

- Server: the core of the logic application of the system. It includes web communication services, such as Service Registry and Service of Information Generation via a map on a web page.

\section{Smart Tags}

As mentioned, the operating scenario is an open and intelligent environment thanks to the fact that smart tags are distributed throughout it where there are objects with visual information.

The user will find the smart tag on the corresponding point of interest, and, at first glance, he will see the name assigned to it (place, location, place of interest, etc.) and/ or icons, images or any other text or visual information on the touristic place. The main role of smart tags is to allow the user to access information and services available on a touristic information desk, in relation to the point of interest where the smart tag is; and to display the different options for the user (any icon / image / text differently deployed in the mobile application) in order to get information about it, and therefore locate it to allow the tourist tracking.

Figure 4 shows the number of ways in which NFC technology can be used for different purposes (there are basically three main categories).

For this proposal, each point of interest or location has a unique identifier (LUID) independent from the smart tag that it belongs to. Each smart tag (a tag is associated with a single point of interest) stores a URI that concatenates the URL of the website and the

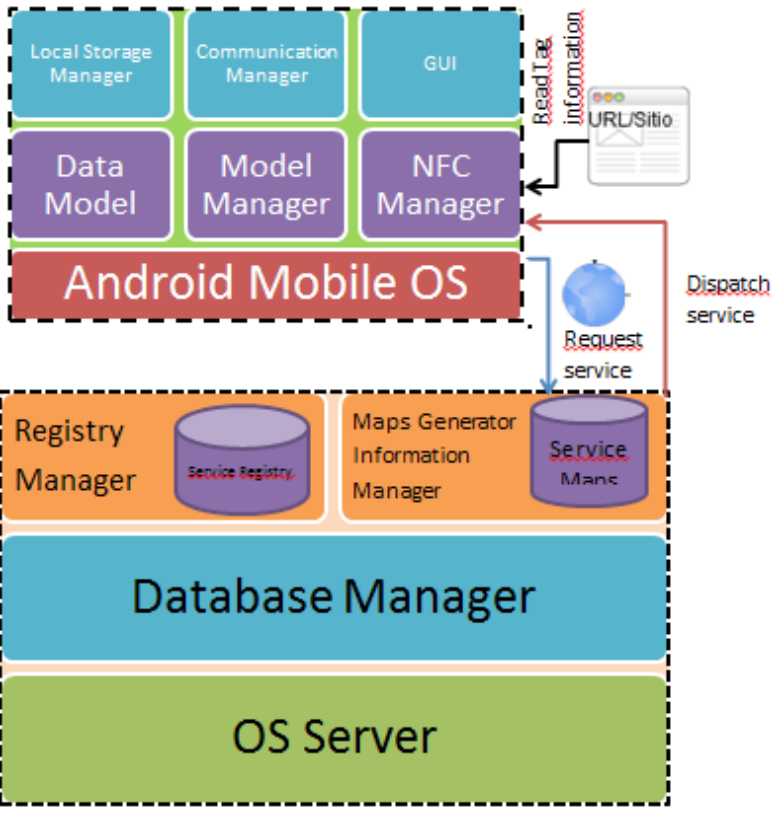

Figure 3. Components of the touristic activity registry system / Figura 3. Componentes del sistema de registro de la actividad turística

racción con el usuario a través de una interfaz gráfica, mostrando los recursos informativos entregados por el servidor. También es el lector de etiquetas NFC. La comunicación se establece en modo pasivo, porque el dispositivo móvil es el que tiene la fuente de alimentación y es el que genera la señal para el intercambio de datos.

- Servidor: núcleo de la aplicación lógica del sistema. Incluye los servicios web de comunicación, como el Servicio de Registro y el Servicio de Generación Información a través de un mapa en una página web.

\section{Smart Tags}

Como se mencionó, el escenario de operación es un entorno abierto e inteligente gracias a las etiquetas inteligentes se propagan a través de él, donde se encuentran objetos con información visual.

\section{Applications}

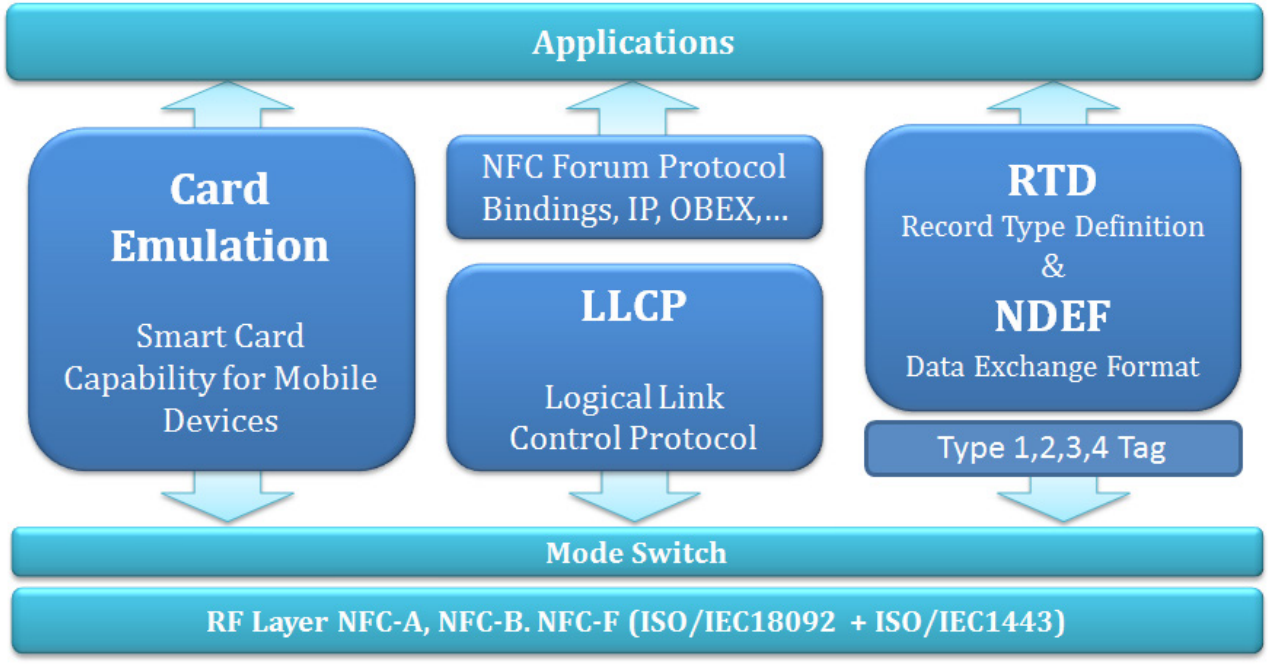

Figure 4. Uses of NFC devices (NFC Forum, 2015) / Figura 4. Usos de dispositivos NFC (NFC Forum, 2015) 
El usuario se encontrará con la etiqueta inteligente colocada en el punto de interés correspondiente, en la que, a primera vista, verá el nombre asignado a la misma (lugar, ubicación, punto de interés, etc.) y/o íconos, imágenes o cualquier otro texto o información visual del sitio turístico. El rol principal de las etiquetas inteligentes es: permitir que el usuario tenga acceso a la información y servicios disponibles en un servicio de información turística, en relación con el lugar de interés donde se encuentra la etiqueta inteligente; y mostrar las diferentes opciones para el usuario (cualquier icono/imagen/texto diferente desplegado en la aplicación móvil) con el fin de obtener información sobre el mismo, y por lo tanto, localizarlo para permitir el seguimiento turístico.

La Figura 4 muestra el número de formas en que se puede utilizar la tecnología NFC para diferentes propósitos (hay básicamente tres categorías principales).

Para esta propuesta, cada punto de interés o ubicación tiene un identificador único (LUID) independiente de la etiqueta inteligente a la que pertenece. Cada etiqueta inteligente (una etiqueta se relaciona con un punto de interés único) almacena una URI que concatena la URL de la página web y el punto de interés $L U I D$, con el fin de permitir al usuario el acceso en modo fuera de línea a:

- el nombre del punto de interés o la ubicación;

- una breve descripción del punto de interés relacionado con el Tag;

- una imagen (icono) que corresponde con el punto de interés;

- las coordenadas físicas donde se coloca la etiqueta inteligente; y

- las coordenadas físicas del punto de interés relacionado con el Tag.

Cada módulo ha sido diseñado y desarrollado con el fin de mantener lo más débilmente acoplados posible los componentes de la arquitectura. La interacción entre módulos se realiza a través de interfaces de servicios Web, reduciendo al mínimo la dependencia de las opciones tecnológicas y de ejecución.

\section{Cliente móvil}

Este módulo corresponde a una aplicación móvil Android que implementa la interfaz gráfica de usuario que gestiona la interacción con los turistas. Su implementación se basa en la plataforma Java Android. El diseño y desarrollo se basa en el paradigma Modelo-Vista-Controlador, patrón arquitectónico que tiene como objetivo aislar la lógica de negocio de la interfaz de usuario, por lo que es más fácil de modificar, ya sea la apariencia visual o las reglas de negocio subyacentes de una aplicación, sin afectar al otro.

El modelo representa la lógica de negocio y es implementado por las siguientes clases: NFC Manager, Data Model, Model Manager, Communication Manager y Local Storage Manager. El Data Model representa los datos manejados por la aplicación y contiene un subconjunto de entidades que cargan el modelo de información conceptual del sistema.

El NFC Manager utiliza el API NFC de Android, que permi- point of interest $L U I D$, in order to allow the user access in offline mode to:

- the name of the point of interest or location;

- a brief description of the point of interest associated with the tag;

- an image (icon) corresponding to the point of interest;

- the physical coordinates where the smart tag is placed; and

- the physical coordinates of the point of interest related to the tag.

Each module has been designed and developed to keep the architecture components coupled as weakly as possible. The interaction between modules is done through web services interfaces, reducing the dependence on technology and execution options to a minimum.

\section{Mobile client}

This module corresponds to an Android mobile application that implements the graphical user interface that manages the interaction with tourists. Its implementation is based on the Java Android platform. The design and development is based on the Model-View-Controller architectural pattern that aims to isolate business logic from the user interface, so it is easier to modify either the visual appearance or the rules underlying the business application without them affecting each other.

The model represents the business logic and is implemented by the following classes: NFC Manager, Data Model, Model Manager, Communication Manager and Local Storage Manager. The Data Model represents the data handled by the application and contains a subset of entities that load the conceptual information model of the system.

The NFG Manager uses the NFG API of Android, which allows NFG data to be sent and received as NDEF messages. The reading of the NDEF data of an NFC tag is handled with the tag sending system and is carried out by creating an Intent that encapsulates and identifies the information, specifically through the use of ACTION_ TAG_DISCOVERED, and intercepts the time when the tag is read to perform a specific action.

Figure 5 shows the format of NFC Data Exchange, a lightweight binary message format designed to encapsulate one or more application payloads in the constructor of the simple message. Each NDEF Message consists of one or more NDEF Records. Each NDEF Record can carry a payload of an arbitrary type and up to $2^{\wedge} 31-1$ bytes in size. If the load is greater, the records can be chained to support larger data. 


\section{NDEF Message}

\begin{tabular}{|c|c|c|c|c|c|c|}
\hline \multirow{2}{*}{$\begin{array}{l}\text { NDEF Message } \\
\text { (variable lenght) } \\
\text { NDEF Records } \\
\text { (variable lenght) }\end{array}$} & \multicolumn{2}{|c|}{ NDEF Record } & \multicolumn{2}{|c|}{ NDEF Record } & \multicolumn{2}{|c|}{ NDEF Record } \\
\hline & Record Header & Record Payload & $\begin{array}{l}\text { Record } \\
\text { Header }\end{array}$ & $\begin{array}{l}\text { Record } \\
\text { Payload }\end{array}$ & $\begin{array}{l}\text { Record } \\
\text { Header }\end{array}$ & $\begin{array}{l}\text { Record } \\
\text { Payload }\end{array}$ \\
\hline & \multicolumn{2}{|c|}{$\begin{array}{c}\text { Record 1: } \\
\text { Contact's name }\end{array}$} & $\begin{array}{r}\text { Record } \\
\text { phon }\end{array}$ & $\begin{array}{l}\text { ontact's } \\
\text { mber }\end{array}$ & \multicolumn{2}{|c|}{ Record 3: URL } \\
\hline
\end{tabular}

Figure 5. NDEF Message (Roland \& Langer, 2010) / Figura 5. NDEF Message (Roland \& Langer, 2010) te enviar y recibir datos NFC en forma de mensajes NDEF. La lectura de datos NDEF de una etiqueta NFG se maneja con el sistema de etiquetas de envío y se lleva a cabo con la creación de un Intent que encapsula e identifica la información, específicamente por medio del uso del ACTION_ TAG_DISCOVERED, e in-
The Model Manager manages the interaction between the Controller, the view and the other modules that implement the model. Similarly, any invocation of services provided by the Communication Manager and the Local Storage Manager is managed by the Model Manager. The Communication Manager manages communication based on HTTP and RESTful web services between the mobile and the server in order to send the information on the visit. The Local Storage Manager manages the local storage database through a SQLite database engine.

The view is responsible for showing the application data in elements of the user interface; simple textual user interfaces are presented.

The controller manages the user's requests, which may involve changes in the data model or communication requests with the server through the Communication Manager.

The architecture of the mobile application has been designed with the objective of allowing the incremental development of the provision of information about tourism elements (brief description, services offered through the official website, etc.).

\section{Server}

The server contains the application logic for web services. It consists of the following main modules:

- Registry Manager, which manages the recording service of visits to the places of interest in the database, along with the time information obtained.

- Maps Generator Information Manager, which manages the deployment service of visits information via maps in a web page.

For the latter purpose the GMap component of the PrimeFaces library (a set of JSF components) (PrimeFaces, 2014) was used, which is built with Google Maps API version 3 , integrated with the JSF programming model and enhanced with Ajax capabilities. This API is used to display on a map the traceability of the route tercepta el momento en el que es leída la etiqueta para llevar a cabo una acción específica.

La Figura 5 muestra el formato de intercambio de datos de $\mathrm{NFC}$, un formato de mensaje binario ligero, diseñado para encapsular una o más cargas útiles de aplicación en el constructor del mensaje simple. Cada NDEF Message consta de uno o más NDEF Records. Cada NDEF Record puede transportar una carga útil de un tipo arbitrario y hasta $2 \wedge 31-1$ octetos de tamaño. Si la carga es mayor, los registros se pueden encadenar para apoyar datos más grandes.

El Model Manager gestiona la interacción entre el Controller, la vista y los otros módulos que implementan el modelo. Análogamente, cualquier invocación de los servicios proporcionados por el Communication Manager y el Local Storage Manager es gestionado por el Model Manager. El Communication Manager gestiona la comunicación basada en HTTP y servicios web REST-Ful entre el móvil y el servidor, con el fin de enviar la información de la visita. El Local Storage Manager gestiona la base de datos de almacenamiento local a través del motor de base de datos SQLite.

La vista es responsable de mostrar los datos de aplicación en elementos de la interfaz de usuario; se presentan interfaces de usuario textual simples.

El controlador gestiona las solicitudes del usuario, las que pueden implicar cambios en el modelo de datos o solicitudes de comunicación con el servidor mediante el Communication Manager.

La arquitectura de la aplicación móvil ha sido diseñada con el fin de permitir el desarrollo incremental de la entrega de información sobre los elementos turísticos (breve descripción, servicios ofrecidos a través de la web oficial, etc.).

\section{Servidor}

El servidor contiene la aplicación lógica para los servicios web. Se compone de los siguientes módulos principales:

- Registry Manager, que gestiona el servicio de registro de las visitas a los puntos de interés en la base de datos, junto con la información de tiempo obtenida.

- Maps Generator Information Manager, que gestiona el servicio de despliegue de información de visitas a través de mapas en una página web.

Para este último propósito se empleó el componente GMap de la librería Primefaces (un conjunto de componentes JSF) (PrimeFaces, 2014), que es construido con Google Maps API 
versión 3, integrado con el modelo de programación JSF y mejorado con capacidades Ajax. Esta API se utiliza para mostrar en un mapa la trazabilidad de la ruta seguida por un turista específico, así como también la ubicación de los sitios de interés, junto con el número de visitas que se han realizado a cada uno de los sitios.

El servidor ha sido diseñado y desarrollado como una aplicación f2EE (Gava 2 Enterprise Edition). Así, la arquitectura del servidor consiste en una capa de presentación a través de mapas, una capa de lógica de aplicación de servicios y una capa de base de datos.

El intercambio de mensajes con las instancias de aplicaciones móviles se implementa de acuerdo con las especificaciones de servicios web, a través de la API de Java para servicios web XML-base (JAX-WS). Los servicios han sido implementados utilizando los servicios web RESTful JAX-RS. Los procedimientos se llevaron a cabo utilizando los servicios web de lenguaje Java con Jersey y compilados para la obtención de la aplicación de servidor.

La capa de base de datos gestiona el acceso a la información de base de datos. Los datos de la aplicación del sistema se conservan en una base de datos MySQL; se accede por medio del API fava Persistence.

\section{Resultados experimentales}

El propósito de la experiencia piloto permite comprobar la hipótesis: se puede capturar la información dejada por parte de los turistas al visitar una Smart City por medio de herramientas tecnológicas, en este caso con la tecnología NFC permitiendo su interacción con el ambiente, con el procesamiento de dicha información se puede obtener una traza que sea la muestra de la actividad realizada, por el turista o visitante, lograr la visualización de esa traza permitirá la toma de decisiones que favorezcan la actividad turística como parte de la economía regional y nacional.

Se implementó un prototipo de la arquitectura descrita, desarrollado en Java; las etiquetas inteligentes se escribieron en formato de mensaje NDEF, formato de mensaje encapsulado para intercambiar información entre dispositivos NFC, específicamente una URL que es de tipo Uniform Resource Identifier (URI) (Remedios et al., 2006). El cliente móvil se implementó en la plataforma Android y se ejecutó sobre un smartphone LG Nexus 4, con capacidades de red y NFG. El servidor fue implementado como una aplicación Web J2EE (Java 2 Enterprise Edition); la capa de comunicación utiliza los servicios web RESTful JAX-WS con Jersey; la base de datos fue implementada con el motor MySQL.

En la TABla 1 se presenta un resumen de las herramientas hardware y software más destacadas, utilizadas en el diseño, implementación, despliegue y análisis del prototipo implementado. Igualmente se muestra a que nivel está cada herramienta, destacando herramientas a nivel de ciudad, como las etiquetas, y a nivel de turista, como el teléfono móvil.

La Figura 6 muestra las interfaces gráficas del prototipo móvil implementado, el lado izquierdo corresponde al inicio de la aplicación -al solicitar al turista que toque la etiqueta-, el derecho, al sitio web móvil desplegado acorde con la información ubicua. followed by a specific tourist, as well as the location of the places of interest, along with the number of visits to each of the sites.

The server has been designed and developed as a $72 E E$ application (fava 2 Enterprise Edition). Thus the server architecture consists of a presentation layer through maps, a layer of services application logic, and a database layer.

The exchange of messages with instances of mobile applications is implemented according to the specifications of web services, through the Java API for XML-Based Web Services (JAX-WS). The services have been implemented using RESTfulJAX-RS web services. The procedures were carried out using web Services of Java language with Jersey and compiled to obtain the server application.

The database layer manages access to the information of the database. Data from the application of the system are stored in a MySQL database, accessed via the Fava Persistence API.

\section{Experimental results}

The purpose of the pilot experiment allows testing of the hypothesis: the information left by tourists visiting a Smart City through technological tools can be captured, in this case with NFC technology allowing its interaction with the environment; with processing of this information a trace that is the sample of the activity done by the tourist or visitor can be obtained; achieving the visualization of that trace will allow beneficial decision-making that can promote tourism as part of the regional and national economy.

A prototype of the described architecture, developed in Java, was implemented; smart tags were written in NDEF message format, message encapsulation format to exchange information between NFG devices, specifically a URL of the type Uniform Resource Identifier (URI) (Remedios et al., 2006). The mobile client was implemented on the Android platform and executed on a LG Nexus 4 smartphone with network and NFG capabilities. The server was implemented as a Web J2EE (Java 2 Enterprise Edition) application; the communication layer uses RESTful JAX-WS Web Services with Jersey; the database was implemented with the MySQL engine.

TABLE 1 summarizes the most important hardware and software tools used in the design, implementation, deployment and analysis of the implemented prototype. Also, it is shown at which level each is, highlighting city level tools, such as tags, and those at the level of the tourist, like a mobile phone. 
Figure 6 shows the graphical interfaces of the mobile prototype implemented, where the left side corresponds to the start of the application -when it solicits the tourist touching the tag-, and at the right side the mobile website is deployed according to the ubiquitous information.

Figure 7 shows the map deploying the points visited according to the activity of the tourist with the mobile. Figure 8 shows the graph of movement, according to the trace generated by a tourist, thanks to the implementation of the previously defined architecture, which obtains data from a database implemented with the MySQL engine, prior to storage using the web communication established between the server and the mobile application at the moment of being used by the tourist to record his visits to the places of the city through NFC. The maps deployed on the web server use PrimeFaces for the deployment of Google maps on screen.

With the data obtained from the proposed solution, i.e. the mo-
Table 1. Set of tools used / Tabla 1. Conjunto de herramientas utilizadas

\begin{tabular}{|c|c|c|}
\hline Tool / Herramienta & Description / Descripción & Level / Nivel \\
\hline NFG Forum tags / Etiquetas NFC Forum & Topaz type 1 & City / Ciudad \\
\hline Mobile telephone / Telefono móvil & LG Nexus 4 & Tourist / Turista \\
\hline $\begin{array}{l}\text { Environment of software development } \\
\text { / Entorno de desarrollo software }\end{array}$ & Netbeans IDE version 7.1 & Mobile / Móvil \\
\hline $\begin{array}{l}\text { Java platform for mobile development } \\
\text { / Plataforma fava para desarrollo móvil }\end{array}$ & Android SDK & Mobile / Móvil \\
\hline $\begin{array}{l}\text { Programming language for mobile } \\
\text { development / / Lenguaje de programación para } \\
\text { desarrollo móvil }\end{array}$ & Java & Mobile / Móvil \\
\hline Database manager / Gestor de base de datos & MySQL Server & System / Sistema \\
\hline Operative system / Sistema operativo & Windows 7 Enterprise Edition & System / Sistema \\
\hline $\begin{array}{l}\text { Analysis and statistical calculation / } \\
\text { Cálculo y análisis estadístico }\end{array}$ & SPSS Version 15.0 & Analysis / Análisis \\
\hline
\end{tabular}
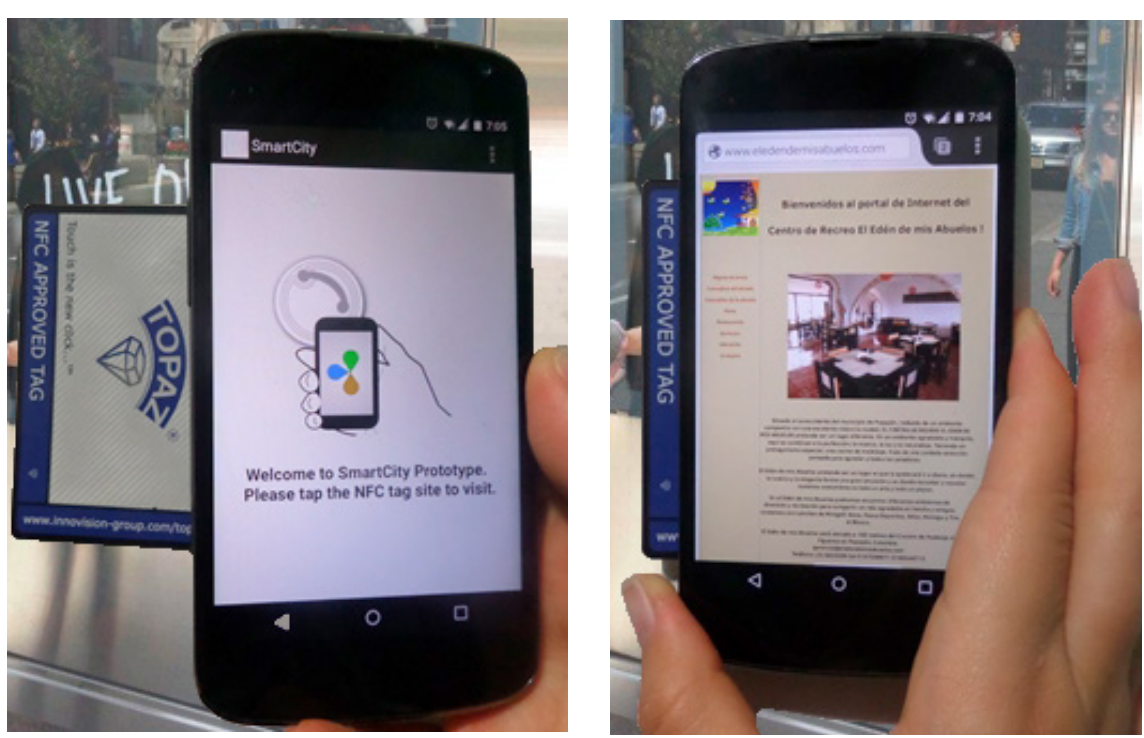

Figure 6. Implementation of the mobile prototype / Figura 6. Implementación del prototipo móvil

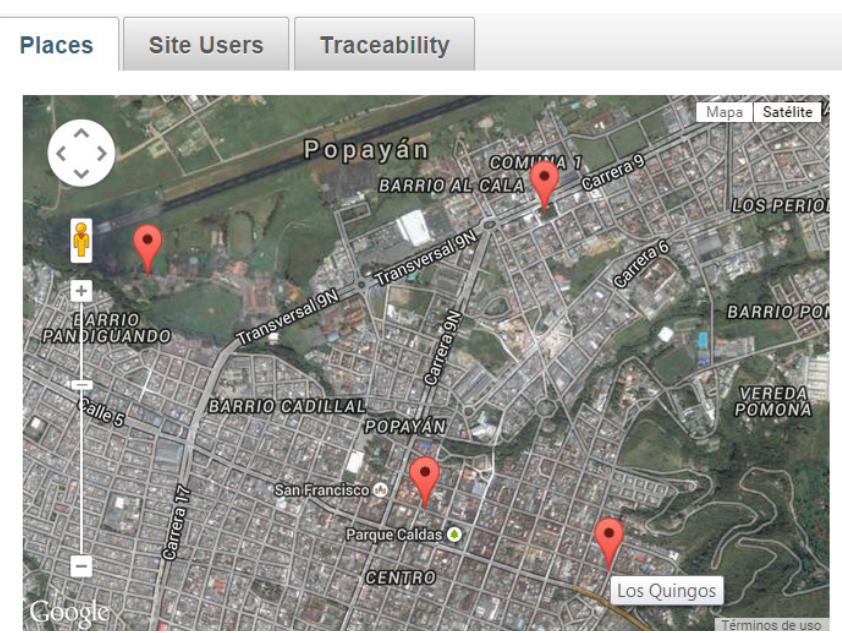

Figure 7. Mapping of visits / Figura 7. Mapeo de visitas

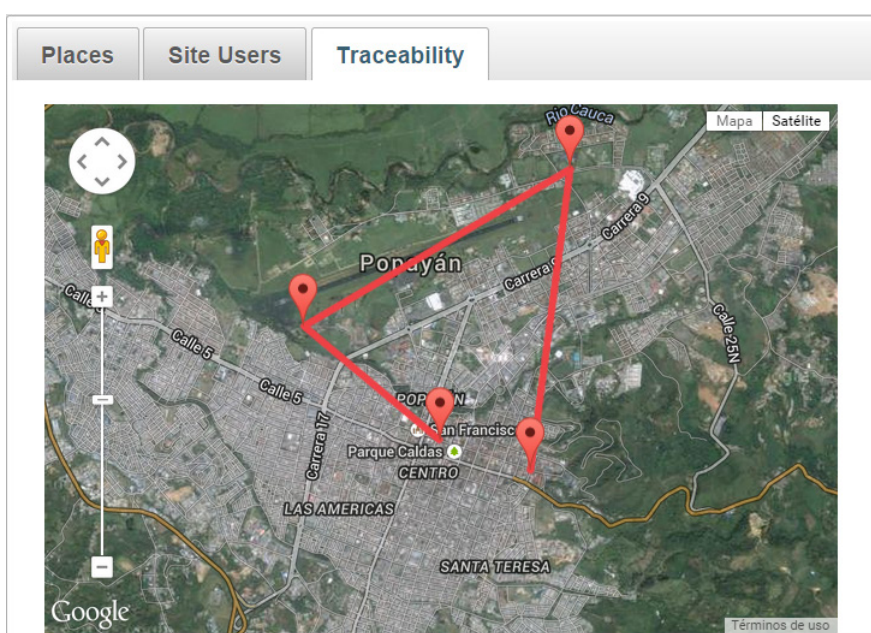

Figure 8. Movement in maps of the zone / Figura 8. Movimiento en mapas de la zona 
En la Figura 7 se muestra el mapa desplegando los puntos visitados acorde con la actividad del turista con el móvil; en la Figura 8, el gráfico del movimiento, acorde con la traza generada por un turista, gracias a la implementación de la arquitectura previamente definida, la cual obtiene los datos de una base de datos implementada con el motor MySQL, previo almacenamiento por medio de la comunicación web establecida entre el servidor y la aplicación móvil, al ser empleada por el turista para registrar sus visitas a los sitios de la ciudad por medio de NFC. Los mapas desplegados en el servidor web emplean la librería PrimeFaces para realizar el despliegue de los mapas de google en pantalla.

Con los datos obtenidos de la solución propuesta, es decir con los movimientos de un turista en una Smart City en el espacio-tiempo, se puede realizar un análisis empleando cadenas de Markov para determinar patrones de movilidad. Para ello se partió del conjunto de datos del «Proyecto Piloto de Trazabilidad Turística» en la ciudad de Popayán (Hurtado 2011; Ramirez-Gonzáles, Chantre, \& Delgado, 2014), replicando los datos en un escenario controlado de etiquetas NFG, representándolos bajo el sistema ubicuo de despliegue propuesto. Este análisis consiste en evaluar los diferentes movimientos de los turistas, a partir de un conjunto de datos reales y sus transiciones, durante su visita en la ciudad Popayán en Semana Santa.

Para contextualizar el escenario, la zona de despliegue fue un mapa de la ciudad de Popayán, capital del departamento del Cauca (Colombia), localizada en el valle de Pubenza, entre las cordilleras Occidental y Gentral, al sur occidente del país. Algunos lugares de interés con los que cuenta la ciudad son: el Morro de Tulcán; el parque Caldas; la Universidad del Cauca; la Torre del Reloj; el Puente del Humilladero; algunas iglesias, como San Francisco, Santo Domingo, San Agustín, La Ermita, San José y Belén; y algunos museos, entre ellos, la Casa-Museo Mosquera, el Museo Arquidiocesano de Arte Religioso, el Museo Nacional Guillermo Valencia y el Museo de Historia Natural.

Siguiendo con el análisis, se utiliza la técnica de cadenas de Markov en el modelamiento del movimiento espacio temporal del turista, además de realizar la validación del modelo mediante el método chi-cuadrado de Pearson o bondad de Ajuste. Así, se denota un proceso estocástico como una variable aleatoria de estados que evoluciona en el tiempo $\left\{X_{t}\right\} t \in T$ de forma parcial o totalmente aleatoria en un determinado espacio de probabilidad $S$ e indexado por índice t que pertenece a un conjunto de parámetros $T$. Se establece t como la variable de tiempo $T=1,2,3, \ldots$.

$\left\{X_{\mathrm{t}}\right\} t \in T$ se representará como los diferentes estados o lugares turísticos asociados al Proyecto de Trazabilidad denominados PATs que el turista visita en Popayán.

En primera instancia se obtuvo un grafo que permite visualizar las transiciones presentes, de un estado a otro, con sus respectivas probabilidades, que fue derivado de una matriz de transición con la suma de todas las secuencias de movimientos por turista y las frecuencias de visita a cada lugar turístico, como también las frecuencias de movimientos de un estado al siguiente. vements of a tourist in a Smart City in space and time, an analysis using Markov chains to determine mobility patterns can be performed. For this, the starting point was the data set of the «Pilot Project of Touristic Traceability» in the city of Popayan (Hurtado, 2011; Ramirez-Gonzáles, Chantre, \& Delgado, 2014), replicating data in a controlled NFG tags scenario, depicting them under the ubiquitous deployment system proposed. This analysis consists in evaluating the different movements of tourists from a real dataset and their transitions, during their visit to Popayan city at Easter.

To contextualize the scenario, the deployment area was a map of the city of Popayan, capital of the department of Cauca (Colombia), located in the valley of Pubenza, between the Western and Central mountain ranges, in the southwest of the country. Some places of interest of the city are: the Morro de Tulcán; Caldas Park; Universidad del Cauca; Torre del Reloj; Puente del Humilladero; some churches, such as San Francisco, Santo Domingo, San Agustín, La Ermita, San José and Belén; and several museums, including the Casa-Museo Mosquera, the Museo Arquidiocesano de Arte Religioso, the National Museum Guillermo Valencia and the Museum of Natural History.

Continuing with the analysis, the Markov chains technique is used in modeling the spatio-temporal movement of the tourist, apart from validation of the model by Pearson's chi-square method or goodness of fit. Thus, a stochastic process is denoted as a random variable of states that evolves throughout time $\left\{X_{\mathrm{t}}\right\} t \in T$ in a partially or totally random manner in a given probability space $\mathrm{S}$ and indexed by a $\mathrm{t}$ index that belongs to a set of parameters $T$. $t$ is established as the time variable: $T=1,2,3, \ldots$

$\left\{X_{t}\right\} t \in T$ will be represented as the different states of touristic places associated with the Pilot Project of Touristic Traceability, denominated PATs, that the tourists visit in Popayán.

In the first instance a graph was obtained that displays the present transitions, from one state to another, with their respective probabilities, which was derived from a transition matrix with the sum of all sequences of movements per tourist and the frequency of visits to each touristic place, as well as the frequency of movements from one state to the next.

Next, in order to validate the modeling, the validation method of Pearson's CM chi-square or goodness of fit is used (Akaike, 2014). 
Therefore, the null hypothesis H0 is raised, by contrast, as the lack of dependence existing between the relative movement of the tourist, from a predecessor touristic place to a successor one (transitions); then, if $\mathrm{H} 0$ is valid, it is concluded that is not reliable to model the tourist's movement through CM.

To perform the analysis of chi-square using SPSS (Statistical Package for the Social Sciences), the number of visits that occur on the possible transitions from one state to another registered is entered, obtaining the results shown in TABLES 2 AND 3.

The value calculated with SPSS software SPSS $X^{2}$ : $=1155,13025$ and degrees of freedom $g l=238$; this value is given by the multiplication $(n-1) *(k-1)$, where ${ }^{n}$ is the number of rows of the matrix and $k$ is the number of columns of the matrix. Because the evaluated matrix is of the order $18 x 18$, the calculated value of $g l$ will be $(18-1) *(18-1)=289$ , but because the matrix has zero transitions to the states (8), (23) and (27), the new value of $k$ will be 15 , thus having the new value of $g l=(18-1) *(15-1)=238$, the value that is obtained using the SPSS program.

Therefore for validation, the critical reference value $X^{2}{ }_{(n-1)(k-1)}$ which is between the values 233.9942 and 287.8815 for a confidence level of $95 \%$ (significance level of 5\%) is compared with the calculated value of $X^{2}:=1155,13025$, showing that the definition $X^{2}>X_{(n-1)(k-1)}^{2}$ is satisfied.

In this manner, we can reject the null hypothesis of a lack of dependence between the relative movement of the tourist from a predecessor touristic place to a successor touristic place (transitions), and conclude that the movement of a tourist is in practice influenced by the state or touristic place where he is to move to another. The validity of modeling the movement of tourists with Markov chains is confirmed.

\section{Conclusions and future work}

Traditional tracking techniques include those based on observations and interviews that require the researcher to follow an individual tourist and record his movements
A continuación para validar el modelamiento se hace uso del método de validación de CM chi-cuadrado de Pearson o bondad de ajuste (Akaike, 2014).

Por lo tanto, se plantea la hipótesis nula Ho a contrastar como la independencia existente entre la relación del movimiento del turista, de un lugar turístico predecesor a un lugar turístico sucesor (transiciones); entonces, si Ho es válida, se concluye que no es confiable modelar el movimiento turístico a través de CM.

Para realizar el análisis de chi-cuadrado utilizando el programa SPSS (Paquete Estadístico para las Ciencias Sociales) se ingresa el número de visitas que se producen en las transiciones posibles de un estado a otro registradas, obteniendo los resultados que se presentan en las TABLAS 2 y 3.

El valor calculado con el software SPSS $X^{2}:=1155,13025$ y grados de libertad $g l=238$; dicho valor es dado por la multiplicación $(n-1) *(k-1)$ donde $n$ es el número de fi-
Table 2. Summary of processing of cases / Tabla 2. Resumen del procesamiento de los casos

\begin{tabular}{lrrl}
\hline Cases $\rightarrow$ / Casos $\rightarrow$ & Valid / Válidos & Lost / Perdidos & \multicolumn{1}{l}{ Total } \\
& & & \\
Rows* columns / Filas * columna & $487(100 \%)$ & $0(0 \%)$ & $487(100 \%)$ \\
\hline
\end{tabular}

Table 3. Chi-square $X^{2}$ tests / Tabla 3. Pruebas de chi-cuadrado $X^{2}$

\begin{tabular}{|c|c|c|c|}
\hline & Value / Valor & gl & $\begin{array}{l}\text { Asymptotic Sig. (bila- } \\
\text { teral)/ Sig. Asintotica (bilateral) }\end{array}$ \\
\hline $\begin{array}{l}\text { Pearson's chi-square / } \\
\text { Chi-cuadrado de Pearson }\end{array}$ & 1155,13025 & 238 & $2,91 \mathrm{E}-120$ \\
\hline $\begin{array}{l}\text { Rate of verisimilitude / } \\
\text { Razón de verosimilitudes }\end{array}$ & 463,477792 & 238 & $1,1523 \mathrm{E}-16$ \\
\hline Linear by linear associa- & 6,62584956 & 1 & 0,01005092 \\
\hline
\end{tabular}

tion / Asociación lineal por lineal

Number of valid cases / 487 las de la matriz y $k$ es el número de columnas de la matriz, como la matriz evaluada es de orden $18 \times 18$, el valor calculado de $g l_{\text {será }}(18-1) *(18-1)=289$, pero como la matriz presenta transiciones nulas a los estados (8), (23) y (27), el nuevo ${ }^{k}$ será de 15 , teniendo así el nuevo valor de $g l=(18-1) *(15-1)=238$, valor que es el obtenido con el programa SPSS.

Así para la validación, el valor de referencia valor crítico $X_{(n-1)(k-1)}^{2}$ que está entre los valores 233,9942 y 287,8815 para un nivel de confianza del 95\% (nivel de significación del $5 \%)$ se compara con el valor calculado $X^{2}:=1155,13025$, evidenciando que se cumple la definición $X^{2}>X^{2}{ }_{(n-1)(k-1)}$

De esta forma se rechaza la hipótesis nula de independencia existente entre la relación del movimiento del turista de un lugar turístico predecesor a un lugar turístico sucesor (transiciones), concluyendo que el movimiento de un turista está influenciado por el estado o sitio turístico donde se encuentre 
para pasar a otro. Se confirma así la validez de Modelar el movimiento de turistas con cadenas de Markov.

\section{Conclusiones y trabajo futuro}

Dentro de las técnicas de tracking tradicionales están las basadas en observaciones y entrevistas que requieren que el investigador siga un turista individual y registre sus movimientos manualmente; mientras, Gracias al avance de las TIC, entre las nuevas técnicas basadas en la tecnología está el uso de dispositivos GPS y de teléfonos celulares para permitir el seguimiento de los turistas en el espacio-tiempo. Generalmente se han usado tecnologías como telefonía móvil celular, Wi-Fi, GPRS, entre otros, para detectar la ubicación de un turista; sin embargo, gracias a las ventajas que ofrece NFC, como el alto nivel de seguridad en la captura de la información y la probabilidad de error mínima en la obtención de datos de usuario, esta tecnología se ha utilizado en esta investigación para implementar una novedosa alternativa que permite obtener los datos de la trayectoria de un turista en tiempo real, para posteriormente ser analizados y modelados con el método de cadenas de Markov.

También se puede concluir que es posible modelar los movimientos espacio-temporales de turistas a nivel macro utilizando la metodología MC. Esta metodología utilizando cadenas de Markov es capaz de analizar las tendencias y los resultados de una serie de eventos que se relacionan, ya que dependen unos de otros en un primer orden. En Popayán se llevó a cabo un estudio, en el cual los datos obtenidos fueron analizados mediante esta metodología. Es importante mencionar que el análisis de movimientos de turistas se ha convertido en una herramienta de planificación, cada vez más importante, para el estudio del comportamiento espacial de turistas y su impacto; Dicha información puede también permitir a los planificadores evaluar los efectos de diferentes estrategias para tomar decisiones sobre el desarrollo de productos turísticos, planificación de destino y comercialización.

En trabajos futuros, se propone el análisis y la implementación del sistema de trazabilidad en diferentes sectores de la economía del turismo para generar empleo y nuevos mercados para el país. Asimismo se propone la implementación del prototipo en un escenario real, donde todos los sitios de interés de una Smart City sean etiquetados, para posteriormente ser analizados por las entidades turísticas en tiempo real, para soportar la toma de decisiones y la generación de nuevas estrategias para promocionar dicho destino turístico. También se propone explorar los otros modos de funcionamiento de la tecnología NFC, como peer to peer para que los turistas puedan compartir diferentes tipos de información entre sus dispositivos. Finalmente se propone que en al momento de tocar la etiqueta de un sitio turístico, se implemente un sistema que sea capaz de recomendarle otros sitios a visitar, con base en su perfil o en información demográfica.SRT manually; meanwhile, thanks to the advances in ICT, among the new technology-based techniques is the use of GPS devices and cell phones to allow the tracking of tourists in space and time. Generally, technologies such as mobile cellular, Wi-Fi, and GPRS, among others, have been used to detect the location of a tourist; however, thanks to the benefits NFC offers, such as the high level of security in capturing information and the minimum error probability of obtaining user data, this technology has been used in this research to implement a novel alternative with which to obtain the data path of a tourist in real time and for posterior analysis and modeling with the Markov chains method.

It can also be concluded that it is possible to model the spatio-temporal movement of tourists at the macro level using the MC methodology. This methodology using Markov chains can analyze trends and the results of a series of events that are related, since they depend on each other in a first order. In Popayan a study was conducted in which the obtained data was analyzed using this methodology. It is noteworthy that the analysis of movements of tourists has become an increasingly important planning tool for the study of the spatial behavior of tourists and their impact. Such information may also enable planners to assess the effects of different strategies and to make decisions about tourism product development, destination planning and marketing.

In future work, it is proposed to analyze and implement a traceability system in different sectors of the tourism economy to create jobs and new markets for the country. Likewise, the implementation of the prototype in a real scenario is proposed, where all the sights of a Smart City are tagged, to be subsequently analyzed by tourism entities in real time to support decision-making and the generation of new strategies for promoting that touristic destination. It also proposed to explore other functioning modes of NFG technology, such as peer to peer, so that tourists can share different types of information between their devices. Finally, it is proposed that when touching the tag of a touristic place, a system that is able to recommend other sites to visit, based on the profile or demographic information, is implemented. SET 


\section{References / Referencias}

Ahas, R., Aasa, A., Mark, Ü., Pae, T., \& Kull, A. (2007). Seasonal tourism spaces in Estonia: Case study with mobile positioning data. Tourism Management, 28(3), 898-910.

Ailisto, H., Pohjanheimo, L., Välkkynen, P., Strömmer, E., Tuomisto, T., \& Korhonen, I. (2006). Bridging the physical and virtual worlds by local connectivity-based physical selection. Personal and Ubiquitous Computing, 10(6), 333-344.

Akaike, H. (2014, May). Statistical Inference and Measurement of Entropy. In Scientific Inference, Data Analysis, and Robustness: Proceedings of a Conference Conducted by the Mathematics Research Center, the University of Wisconsin-Madison, November 4-6, 1981 (p. 165). Academic Press.

Arrowsmith, C. \& Inbakaran, R. (2002). Estimating environmental resiliency for the Grampians National Park, Victoria, Australia: a quantitative approach. Tourism Management, 23(3), 295-309.

Arrowsmith, C., Chhetri, P., \& Zanon, D. (2005). Monitoring visitor patterns of use in natural tourist destinations. In Taking Tourism to the Limits: Issues, Concepts and Managerial Perspectives, (pp. 33-52). Amsterdam, The Netherlands: Elsevier

Asakura, Y. \& Iryo, T. (2007). Analysis of tourist behaviour based on the tracking data collected using a mobile communication instrument. Transportation Research Part A: Policy and Practice, 41(7), 684-690.

Bajaj, R., Ranaweera, S. L., \& Agrawal, D. P. (2002). GPS: location-tracking technology. Computer, 35(4), 92-94.

Borrego-Jaraba, F., Ruíz, I. L., \& Gómez-Nieto, M. Á. (2011). A NFC-based pervasive solution for city touristic surfing. Personal and Ubiquitous Computing, 15(7), 731-742.

Buhalis, D. \& Amaranggana, A. (2013). Smart Tourism Destinations. In Information and Communication Technologies in Tourism 2014 (pp. 553-564). Springer International Publishing.

Cheverst, K., Davies, N., Mitchell, K., \& Friday, A. (2000). Experiences of developing and deploying a context-aware tourist guide: the GUIDE project. In Proceedings of the 6th Annual International Conference on Mobile Computing and Networking, 20-31. New York, NY: ACM.

Chon, J., \& Cha, H. (2011). Lifemap: A smartphone-based context provider for location-based services. IEEE Pervasive Computing, 10(2), 58-67.

Coskun, V., Ozdenizci, B., \& Ok, K. (2013). A survey on near field communication (NFC) technology. Wireless Personal Communications, 71 (3), 2259-2294.

Davies, N., Cheverst, K., Mitchell, K., \& Efrat, A. (2001). Using and determining location in a context-sensitive tour guide. Computer, 34(8), 35-41.

Digital Tourism Think Tank [DTTT] (2014). 2014 year in digital travel [video]. Retrieved from http://youtu.be/rJZbtg_irZU

Ducatel, K., Bogdanowicz, M., Scapolo, F., Leijten, J., \& Burgelman, J.-C. (2001). Scenarios for ambient intelligence in 2010 [online]. Seville, Spain: ISTAG. Retrieved from http://www.ist.hu/doctar/fp5/istagscenarios2010.pdf

Dumont, B., Roovers, P., \& Gulinck, H. (2005). Estimation of off-track visits in a nature reserve: a case study in central Belgium. Landscape and Urban Planning, 71(2), 311-321.

Egger, R. (2013). The impact of near field communication on tourism. Journal of Hospitality and Tourism Technology, 4(2), 119-133.

Fennell, D. A. (1996). A tourist space-time budget in the Shetland Islands. Annals of Tourism Research, 23(4), 811-829.

Fundación Telefónica (2011). Smart Cities: un primer paso hacia la Internet de las Cosas. Madrid, Spain: Fundación Telefónica.

Girardin, F., Vaccari, A., Gerber, A., Biderman, A., \& Ratti, C. (2009). Quantifying urban attractiveness from the distribution and density of digital footprints. International Journal of Spatial Infrastructures Research, 4, 175-200

Hadley, D., Grenfell, R., \& Arrowsmith, C. (2003). Deploying location-based services for nature-based tourism in non-urban environments [conference paper in Spatial Sciences Coalition Conference, Canberra-2003].

Haritaoglu, I., Harwood, D., \& Davis, L. (2000). W 4: Real-time surveillance of people and their activities. IEEE Transactions on Pattern Analysis and Machine Intelligence, 22(8), 809-830.

Hurtado, M. (2011). Aportes al proceso administrativo del proyecto de trazabilidad para el sistema de información turística del departamento del Cauca como iniciativa piloto [thesis]. Universidad del Cauca: Popayán, Colombia.

Kuo, R. J., Wang, H. S., Hu, T. L., \& Chou, S. H. (2005). Application of ant K-means on clustering analysis. Computers \& Mathematics with Applications, 50(10), 1709-1724.

Leiper, N. (2003). Tourism management. Australia: Pearson

Loiterton, D. \& Bishop, I. (2005). Virtual environments and location-based questioning for understanding visitor movement in urban parks and gardens [conference paper in Real-time Visualisation and Participation, Dessau-Germany]. Available at http://www.kolleg.loel.hs-anhalt.de/studiengaenge/mla/mla fl/conf/pdf/conf2005/30loiterton_c.pdf

Loke, S. (2005). Context-aware Pervasive systems: Architectures for a new breed of applications. Boca Raton, FL: Auerbach. McLaren, D. (2003). Rethinking tourism and ecotravel. Bloomfield, CT: Kumarian.

Naphade, M., Banavar, G., Harrison, C., Paraszczak, J., \& Morris, R. (2011). Smarter cities and their innovation challenges. Computer, 44(6), 32-39.

NFC Forum (2015). [online]. Retrieved from http://nfc-forum.org/

O'Connor, A., Zerger, A., \& Itami, B. (2005). Geo-temporal tracking and analysis of tourist movement. Mathematics and Computers in Simulation, 69(1), 135-150. 
Ogilvie, F. (1933). The tourist movement: An economic study. London, UK: PS King \& Son.

O'Neill, E., Kostakos, V., Kindberg, T., Penn, A., Fraser, D. S., \& Jones, T. (2006). Instrumenting the city: Developing methods for observing and understanding the digital cityscape. In UbiComp 2006: Ubiquitous Computing (pp. 315-332). Berlin-Heidelberg, Germany: Springer

Pearce, D. (1995). Tourism today: A geographical analysis [2 $2^{\text {nd }}$ ed.]. London, UK: Longman Scientific \& Technical.

Pesonen, J. \& Horster, E. (2012). Near field communication technology in tourism. Tourism Management Perspectives, 4, 11-18.

PrimeFaces (2014). [online]. Retrieved from http://www.primefaces.org/

Ramirez, G., Chantré, A., \& Delgado, C. (2014). Proyecto piloto de trazabilidad turística [internal document]. Universidad del Cauca: Popayán, Colombia.

Remedios, D., Sousa, L., Barata, M., \& Osorio, L. (2006). NFC technologies in mobile phones and emerging applications. In Information Technology for Balanced Manufacturing Systems (pp. 425-434). New York, NY: Springer.

Roland, M. \& Langer, J. (2010). Digital signature records for the NFC data exchange format. In Near Field Communication (NFC), 2010 Second International Workshop on, (pp. 71-76). Piscataway, NJ: IEEE.

Ronay, E. \& Egger, R. (2013). NFC smart city: Cities of the future-a scenario technique application. Information and Communication Technologies in Tourism 2014 [Proceedings of the International Conference in Dublin, Ireland, January 21-24, 2014], (pp. 565-577). Cham, Switzerland: Springer.

Russo, A. P., Clave, S. A., \& Shoval, N. (2010). Advanced visitor tracking analysis in practice: explorations in the PortAventura theme park and insights for a future research agenda. Information and Communication Technologies in Tourism 2010, 159-170.

Spitzer, F. (1964). Principles of random walk. New York, NY: Springer.

Tchetchik, A., Fleischer, A., \& Shoval, N. (2009). Segmentation of visitors to a heritage site using high-resolution time-space data. Journal of Travel Research, 48(2), 216-229.

Tiru, M., Kuusik, A., Lamp, M. L., \& Ahas, R. (2010). LBS in marketing and tourism management: measuring destination loyalty with mobile positioning data. Journal of Location Based Services, 4(2), 120-140.

Tobler, W. (1997). Movement modelling on the sphere. Geographical and Environmental Modelling, 1(1), 97-103.

United Nations World Tourism Organization [UNWTO]. (2014, Jan. 20). International tourism exceeds expectations with arrivals up by 52 million in 2013 [press release]. Retrieved from http://media.unwto.org/press-release/2014-01-20/international-tourism-exceeds-expectations-arrivals-52-million-2013

Van Setten, M., Pokraev, S., \& Koolwaaij, J. (2004). Context-aware recommendations in the mobile tourist application COMPASS. Lecture Notes in Computer Science [Adaptive hypermedia and adaptive web-based systems], 3137, 235-244

Wang, B. \& Manning, R. (1999). Computer simulation modeling for recreation management: A study on carriage road use in Acadia National Park, Maine, USA. Environmental Management, 23(2), 193-203.

Wang, Y., Lim, E. P., \& Hwang, S. Y. (2006). Efficient mining of group patterns from user movement data. Data \& Knowledge Engineering, 57(3), 240-282.

Xia, J. \& Arrowsmith, C. (2005). Managing scale issues in spatio-temporal movement of tourists modelling. In International Congress on Modelling and Simulation. Retrieved from http://ip-103-1-174-100.ip.secureserver.net/modsim05/papers/xia. pdf

Xia, J. (2007). Modelling the spatial-temporal movement of tourists [PhD thesis]. RMIT University: Melbourne, Australia

Xia, J., Zeephongsekul, P., \& Arrowsmith, C. (2009). Modelling spatio-temporal movement of tourists using finite Markov chains. Mathematics and Computers in Simulation, 79(5), 1544-1553.

Zimmermann, K. F. \& Constant, A. F. (2003). The dynamics of repeat migration: A Markov chain analysis [discussion paper online]. Retrieved from http://www.econstor.eu/handle/10419/18135 


\section{CURRICULUM VITAE}

Eliana Andrea Concha Agredo Electronics and Telecommunications Engineer (Universidad del Cauca, Popayán-Colombia, 2012). She has professional experience in development of web and mobile applications and entrepreneurial information systems. Her research interests are oriented toward ubiquitous computing, innovation, development of mobile intelligent systems, and project management. Currently she is pursuing a Master's degree in Telematics Engineering at the Universidad del Cauca. / Ingeniera en Electrónica y Telecomunicaciones de la Universidad del Cauca (Popayán-Colombia, 2012). Sus áreas de desempeño profesional han sido el desarrollo de aplicaciones bajo entornos web y móvil, y el desarrollo de sistemas de información a nivel empresarial. Su interés de investigación está orientado hacia la computación ubicua, la innovación y el desarrollo de sistemas inteligentes móviles, y la dirección de proyectos. Actualmente cursa la Maestría en Ingeniería Telemática en la Universidad del Cauca.

Luis Carlos Martínez-Acosta Electronics and Telecommunications Engineer (Universidad del Cauca, Popayán-Colombia, 2012), currently working in management of telematics projects. His main interest areas are advanced telecommunications services and technology management. / Ingeniero en Electrónica y Telecomunicaciones (2012) de la Universidad del Cauca. Actualmente se desempeña en áreas profesionales de gestión de proyectos telemáticos. Sus áreas de interés son los servicios avanzados de telecomunicaciones y la gestión de tecnología.

Gustavo Ramírez-González Electronics and Telecommunications Engineer (2001), Master in Telematics Engineering (2006), and Ph.D. in Telematics Engineering (Universidad Carlos III de Madrid, Spain, 2010). Currently professor and researcher at the Telematics Department at the Universidad del Cauca (Popayán, Colombia). He has participated in several national and international projects, in Colombia and Spain. His main areas of interest are mobile and pervasive computing, and advanced services in telecommunications. / Ingeniero en Electrónica y Telecomunicaciones (2001) y Magister en Ingeniería Telemática (2006) de la Universidad del Cauca. Recibió su título de Doctor en Ingeniería Telemática por la Universidad Carlos III de Madrid (España, 2010). Actualmente es docente e investigador del Departamento de Telemática en la Universidad del Cauca. Ha participado en proyectos nacionales e internacionales en Colombia y España. Sus áreas de interés son la computación móvil, la computación ubicua y los servicios avanzados de telecomunicaciones.

Ángela Chantre Astaiza Business Administrator (Universidad del Cauca, Popayán, Colombia) and Master in Marketing (Universidad Rey Juan Carlos, Madrid, Spain, 2009), currently pursuing her doctoral studies at the same university. She is a professor and researcher at the Department of Tourism Sciences at the Universidad del Cauca and member of the research group on tourism and regional development. She has participated in national and international projects in Colombia and Spain. Her main areas of interest are marketing and technologies applied to tourism. / Administradora de Empresas de la Universidad del Cauca. Recibió su título de Master en Marketing (2009) por la Universidad Rey Juan Carlos (Madrid, España) y actualmente cursa sus estudios de doctorado en la misma Universidad. Es docente e investigadora del Departamento de Ciencias del Turismo de la Universidad del Cauca y miembro del Grupo de Investigación en Desarrollo Turístico y Regional. Ha participado en proyectos nacionales e internacionales en Colombia y España. Sus áreas de interés son el marketing turístico y las tecnologías aplicadas al turismo. 